\title{
Recognition Discourse and Systemic Gender Injustice: An Essay in Honour of Mary-Anne Elizabeth Plaatjies-Van Huffel
}

\author{
Robert Vosloo \\ https://orcid.org/0000-0002-7144-9644 \\ Stellenbosch University \\ rrvosloo@sun.ac.za
}

\section{Abstract}

Against the backdrop of the South African Reformed ecclesiologist Mary-Anne Elizabeth Plaatjies-Van Huffel's reflections on gender insensitivity in church and society, this article engages with the notion of recognition, a concept that has found strong currency in many contemporary discourses. The first part of the article mentions the promise of recognition as a moral, political, and also theological category. In addition, it also interrogates the term in conversation with theorists who raise some critical concerns regarding accounts of recognition that are not adequately justice-sensitive. The second part of the article enters more directly into conversation with some of the writings of Plaatjies-Van Huffel, highlighting in the process her emphasis that the recognition of women should not be dislocated from a plea for a change in the dynamics of patriarchal power and structural gender injustice. The article concludes with a call to move beyond what is termed "cheap recognition."

Keywords: Mary-Anne Elizabeth Plaatjies-Van Huffel; recognition; justice; gender insensitivity; patriarchal power

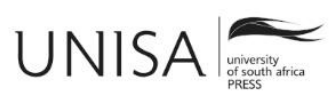




\section{Introduction}

In her article, "A History of Gender Insensitivity in URCSA," the South African Reformed ecclesiologist, Mary-Anne Elizabeth Plaatjies-Van Huffel, ${ }^{1}$ utilises an autoethnographical methodology intending to sensitise readers to what she describes as "issues of identity politics" in the Uniting Reformed Church in Southern Africa (URCSA). She expresses the hope that the research would "enlighten readers to experiences shrouded in silence ... and would deepen knowledge about the struggles women in ordained positions in URCSA had to endure" (Plaatjies-Van Huffel 2019, 2). Her article reflects deeply on how her own remarkable personal narrative- as the first ordained woman minister in her church, as well as this church's first woman moderator of the General Synod-is intertwined with a history of overt and covert gender insensitivity and the dynamics of patriarchal power attitudes and structures. She proposes that the issue of women in leadership should be addressed from a gendersensitive perspective that "will assess critically the gender-biased power relations between men and women" (Plaatjies-Van Huffel 2019, 8).

It is not the purpose of this article to discuss Plaatjies-Van Huffel's leadership role in her denomination and her role as a theological and ecumenical pioneer; rather, against the backdrop of her embodied plea over many decades for gender justice in church and society, I will engage critically with the notion of "recognition." This article wants to acknowledge the promise of recognition as a crucial moral, political and theological category, but at the same time wants to challenge accounts of recognition that do not adequately address expressions of systemic injustice, as well as the way it is experienced and evokes a response. With this in mind, the first part of the article briefly mentions the fact that the language of recognition has found strong currency in contemporary discourses. This section also discusses some critical concerns raised by scholars such as Kelly Oliver and Cillian McBride against reductive accounts of recognition. The second part of the article enters more directly into conversation with some of the writings of Plaatjies-Van Huffel, highlighting in the process her emphasis that the struggle for recognition is about more than women merely being ordained or appointed in certain positions, but about the fundamental change of patriarchal mindsets and structures.

1 As the subtitle states, this article is presented in honour of Prof. Dr Mary-Anne Elizabeth PlaatjiesVan Huffel. I had the privilege to be her colleague in the Department of Systematic Theology and Ecclesiology at the Faculty of Theology, Stellenbosch University until she sadly passed away in May 2020. We often discussed the themes addressed in this article. We also co-edited a book together, entitled Reformed Churches in South Africa and the Struggle for Justice: Remembering 1960-1990 (Plaatjies-Van Huffel 2013). 


\title{
The Promise and Problems of Recognition
}

In the introduction to their polemical conversation, published under the title Redistribution or Recognition? A Philosophical-Political Exchange, Nancy Fraser and Axel Honneth $(2003,1)$ write:

\begin{abstract}
"Recognition" has become a keyword of our time. A venerable category of Hegelian philosophy, recently resuscitated by political theorists, this notion is proving central to efforts to conceptualize today's struggles over identity and difference. Whether the issue is indigenous land claims, or women's carework, homosexual marriage or Muslim headscarves, moral philosophers increasingly use the term "recognition" to unpack the normative bases of political claims. They find that a category that conditions subjects' autonomy on intersubjective regard well captures the moral stakes of many contemporary conflicts.
\end{abstract}

The category of recognition has indeed found fertile ground in the discourses on identity and differences within the identity politics of our day. Given experiences of disrespect and non-recognition, "the struggle for recognition"- to use the Hegelian notion and the title of an influential book by Axel Honneth (English translation 1995) - has found expression in many protest movements around the globe against the systemic persistence of racism, sexism, homophobia, cultural chauvinism, and other harmful strategies of othering. The term "recognition" has a rich and polysemic semantic meaning (see Ricoeur 2005, 1-16), but for the purposes here it will be used mostly to indicate the intersubjective regard through which we acknowledge each other's dignity, rights, common humanity, and differences.

In his important and much-discussed essay, "The Politics of Recognition," first published in 1992, the Catholic moral philosopher Charles Taylor notes the fact that many strands in contemporary politics turn on the need for recognition. This need, Taylor argues, can be seen as one of the driving forces behind some nationalistic political movements, and also comes to the fore "in minority or 'subaltern' groups, in some forms of feminism, and in what is today called the politics of 'multiculturalism"” (Taylor 1994, 25). He also affirms how recognition is linked to identity, to one's understanding of who you are and what defines you as a human being. Therefore, Taylor $(1994,25)$ famously states:

The thesis is that our identity is partly shaped by recognition or its absence, often by the misrecognition of others, and so a person or group of people can suffer real damage, real distortion, if the people or society around them mirror back to them a confining or demeaning or contemptible picture of themselves. Nonrecognition or misrecognition can inflict harm, can be a form of oppression, imprisoning someone in a false, distorted, and reduced mode of being.

Since the publication of Taylor's essay, the need, demand and struggle for recognition is still, and maybe even increasingly so, a defining feature of our current social, ecclesial, economic and geopolitical landscape. In the light hereof it is not surprising 
that theories of recognition are finding greater currency in philosophical and cultural studies, albeit that these accounts have also evoked critical responses. Next to the already mentioned essay of Taylor, one can also think, for instance, of the impact of the studies of the Frankfurt philosopher, Axel Honneth $(1995 ; 2012 ; 2018)$ on the discourse on recognition. Honneth's work is in line with the Critical Theory tradition and seems less directly concerned with the politics of multiculturalism (as, for instance, Taylor), but rather seeks - initially in conversation with the early Hegel-a social theory with normative content in which the possibility of identity-formation rests on the development of self-confidence, self-respect, and self-esteem. This self-realisation is dependent on the establishment of relationships of mutual recognition (Honneth uses the German word Anerkennung in this regard).

Honneth's evolving work on recognition-like that of Taylor-has solicited, and continues to solicit much debate, including a much-discussed response from the American political philosopher, Nancy Fraser, who has critiqued what she views as the decoupling of claims of recognition from those of redistributive justice (see Fraser and Honneth 2003).

One can, furthermore, argue that the notion of recognition also deserves greater traction in theological discourse, and the Finnish Lutheran theologian Risto Saarinen has made an important contribution in this regard through his book, Recognition and Religion: A Historical and Systematic Study (2016). Saarinen challenges the social theorists that see recognition merely as a modern concept stemming from Hegel and neglect religious and theological sources in the intellectual genealogy of the term. Rather, Saarinen claims, "the concept and conceptions of recognition are found in classical, medieval, and early modern religious sources" $(2016,3)$.

For our purposes here, moreover, I want to note - and draw from - the work of some theorists who have problematised further the notion of recognition.

In her book, Witnessing: Beyond Recognition (2001), Kelly Oliver-a philosopher and novelist from Vanderbilt University - for instance, challenges the idea "that the social struggles manifested in critical race theory, queer theory, feminist theory, and various social movements are struggles for recognition" $(2001,8)$. She argues that testimonies from the aftermath of the Holocaust and slavery do not merely articulate a need to be recognised or seen. Rather, Oliver writes $(2001,8)$ :

[T] hey bear witness to a pathos beyond recognition and to something other than the horror of their objectification. They are also testifying to the processes of witnessing that both reconstruct damaged subjectivity and constitute the heart of all subjectivity. The victims of oppression, slavery, and torture are not merely seeking visibility and recognition, but they are also seeking witnesses to horrors beyond recognition. The demand for recognition manifest in testimonies from those othered by dominant culture is transformed by the accompanying demands for retribution and compassion. 
Furthermore, if the dominant group merely confers recognition on others, then the dynamics of hierarchies, privilege and domination are merely repeated. Oppression thus "creates the need in the oppressed to be recognized by their oppressors, the very people most likely not to recognize them" (Oliver 2001, 9). This leaves the oppressed with the sense that they lack something only their dominators can bestow on them. In this way, stereotypes of inferiority and superiority are kept in pace, making recognition a symptom of the pathology of oppression. Or, as Oliver puts it in a later article: "recognition is distributed according to an axis of power that is part and parcel of systems of dominance and oppression" $(2015,474)$.

Oliver also points to Franz Fanon's reference to the Hegelian master-slave dialectic. She argues that although some suggest that he applies the struggle for recognition to a colonial context, Fanon's analysis actually unsettles some contemporary accounts of recognition that presuppose rather than challenge the inherent pathology of recognition within oppressive cultures (see Oliver 2001, 23-44; cf. Fanon 2008, 185-197). She comments:

What Fanon realizes is that the logic of recognition that is part and parcel of colonialism and oppression makes those in power the active agents of recognition and those without power the passive recipients. This is why rather than embrace a recognition model of identity and self-worth, or unproblematically endorse the struggle for recognition of oppressed people, Fanon suggests that active meaning making and self-creation are necessary to fight oppression and overcome the psychic damage of colonialism ... Fanon believes that "man is a yes" to life, love, and generosity but also a no to scorn, degradation, exploitation, and the butchery of freedom. He concludes that to be a yes, humans must be educated to be "actional" not just "reactional." (Oliver 2001, 28, 29; cf. Fanon 1967, 222)

Recognition (understood in a certain way), one can say in the light of Oliver's reading of Fanon, can thus be a symptom of oppression rather than its cure.

In his book simply titled Recognition, Cillian McBride-a political theorist at Queen's University in Belfast - also challenges how debates about recognition are too closely tied with multiculturalism and cultural recognition (Taylor) or seeking normative accounts of recognition (Honneth), and not sufficiently reckoning with systems of power, oppression, and subordination. He critiques what he calls the "recognition deficit" model that pictures a relationship between someone who lacks recognition and then claims it from someone "who has the power to remedy this recognition deficit by granting the recognition which is sought" (McBride 2013, 6). Although McBride does not want to dismiss this model of recognition, this understanding does not address adequately the complexities of the struggles for recognition. According to McBride, this view "diverts our attention away from questions of power and authority" $(2013,6)$. His point is that the desire for recognition can already be part of systems of social domination. McBride also highlights that the recognition-deficit model presents people primarily as passive recipients (a point also made by Oliver 2001). McBride's important 
point is that "some experience too much recognition and use their social prestige to secure their dominance," and thus there is a failure to account for "the processes of social distinction which sustain social inequalities" $(2013,7)$.

McBride challenges, therefore, models of recognition that are not shaped and informed by the wider inequalities of society and destructive power relations. He comments:

An adequate moral and political theory of recognition cannot afford to overlook the dark side of recognition and the thorny problem of the way the pursuit of distinction can work against the pursuit of social equality ... I have reservations about the way that debates about recognition have been too closely associated with multiculturalism, and too isolated from questions about social distinction and social stratification." (McBride 2013,7)

Over and against these reductive approaches, McBride's proposal is for a stronger justice-focused account of recognition.

What these remarks by Oliver and McBride point to is the possibility that recognition discourse, notwithstanding its immense promise for challenging ideals of the autonomous self in favour of an emphasis on intersubjective regard, can easily blind one to the pervasive reality of structures sustaining patterns of oppression, inequality, and injustice. In short, responsible theories of recognition-and also theologies of recognition - should challenge, one can say, reductive accounts that abstract and isolate recognition from concrete socio-historical realities of systemic and structural injustice.

With this in mind, and given the fact that this essay is written in her honour, I want to turn to some of the writings of Plaatjies-Van Huffel that highlight, in my view, concerns similar to the theorists that point towards the need for a justice-sensitive account of recognition.

\section{Recognition, Patriarchy and the Need for Gender Justice}

In the introduction, I referred to Plaatjies-Van Huffel's article "A History of Gender Insensitivity in URCSA," in which she reflects on the experiences of ordained women in her church, and more specifically on her journey in this regard.

In many ways this article also speaks to her academic concerns over the years. Or to put it differently, it indicates how her academic pursuits have been closely interwoven with her life and ministry. Already in her doctoral dissertation, "Vroue in die Teologiese Antropologie van die Afrikaanse Gereformeerde Tradisie" [Women in the Theological Anthropology of the Afrikaans Reformed Tradition] (Plaatjies-Van Huffel 2003; with Christina Landman as supervisor), as well as in some publications in its wake (PlaatjiesVan Huffel and Landman 2005; Plaatjies-Van Huffel in Hansen and Vosloo 2006, she challenges - using a post-structural approach and a historiographical framework - the 
theological anthropology sustaining gender inequality and gender injustice, in particular within the Afrikaans Reformed tradition.

In her writings, Plaatjies-Van Huffel often refers to the fact that Nelson Mandela singled out the importance of gender at the opening of the first democratically elected Parliament, saying:

It is vitally important that all structures of government, including the president himself, should understand this fully: that freedom cannot be achieved unless women have been emancipated from all forms of oppression ... unless we see in visible and practical terms that the condition of the women in our country has radically changed for the better, and that they have been empowered to intervene in all spheres of life as equals with any other member of society (quoted by Plaatjies-Van Huffel 2011a, 259; cf. Plaatjies-Van Huffel 2014, 110).

These words signalled for Plaatjies-Van Huffel the need "to engender patriarchal South Africa towards gender equality/equity" (2011a, 260). Or as she puts it elsewhere, "to transform patriarchy in South African towards gender equality" (Plaatjies-Van Huffel 2014, 111). She sees patriarchy as a system that is in essence androcentric and hierarchical, indeed "a social system that promotes hierarchies and awards economic, political and social power to one group over others" (Plaatjies-Van Huffel 2011a, 260). In fine-tuning the definition of patriarchy, she further draws on the feminist theologian Rosemary Radford Ruether's description of patriarchy as part of the "whole structure of Father ruled society: aristocracy over serfs, masters over slaves, kings over subjects, racial overlords over colonized people" (Plaatjies-Van Huffel 2011a, 260; cf. Ruether 1983, 6). Patriarchy is thus about more than mere attitudes; on a deeper level it is about the structures and ideologies that engender patterns of domination and exploitation. Plaatjies-Van Huffel even connects patriarchy with the term "empire," equating both with " a spirit of lordless domination, created by humankind" (2011a, 261). Therefore, patriarchy should be, to use theological language, rejected as "a structural sin" (2011a, 267), all the more because its imperial logic lacks compassionate justice and regard for the gifts of creation and the household of life.

Plaatjies-Van Huffel emphasises further the need to transform the hierarchical dualism of patriarchal anthropology that allocates social roles to men and women in a way that is characterised by unequal power relations. Concerning the South African context, she writes in this regard: "There is a growing [re]presentation of women in leadership positions in both church and societal structures. However, the presence of women in the ecclesial and societal structures is not an indicator of the transformation of the patriarchal anthropology in South Africa" (Plaatjies-Van Huffel 2011a, 261).

Although Plaatjies-Van Huffel was conscious of the fact that progress has been made over the last decades in the struggle for recognition and gender justice, and that South Africans have a constitution that entrenches equal rights, she was also painfully aware that, in her words, "it is so that discriminatory practices, structural injustices, patriarchy, 
sexism and the social exclusion of women are still thriving in South African churches and civil society" $(2014,111)$.

Given her knowledge of church polity and her interest in the relationship between religion and law, Plaatjies-Van Huffel understood well the importance of laws and policies for gender justice. Yet she also pointed to the fact that legislation is not enough to promote gender equality and equity. Therefore, her observation (2011a, 263):

Legislative reform has provided the building blocks for a gender equitable society. Challenges exist in ensuring that these constitutional, legislative and policy imperatives are transformed into substantive improvements in engendering the society ... the inclusion of women in decision-making structures, however, did not change the dominant discourses which imprisoned women in submissive roles in societal structures.

In her writing, Plaatjies-Van Huffel often underscores this point that it is not enough merely to appoint women in (some) leadership roles in church and society. No, the underlying patriarchal discourses and structures must be transformed. Therefore, it is her view that discriminatory practices cannot be challenged and changed simply by policies on employment equity and other related legislation (although this is extremely important), "but it should rather be redressed through the deconstruction of the sexist and the racist bias of our society and the replacement of the sexist and racist foundational categories of our society with an egalitarian, non-sexist foundation" (Plaatjies-Van Huffel 2011a, 264). The same holds for merely including women in decision-making structures, since sexism and racism should be replaced with “egalitarian, non-sexist ways of living" (Plaatjies-Van Huffel 2014, 112).

As a theologian, Plaatjies-Van Huffel frequently accentuated the need for a more appropriate theological anthropology as a challenge to the dualistic, patriarchal, anthropocentric anthropology that bedevils societal and ecclesial discourses. In this regard, she often affirmed the theological claim that all people-regardless of race, class, or gender - are created in the image of God. This means that men and women "stand as equal partners next to each other in their relationship to God and are joint bearers of the image of God (imago Dei)" (Plaatjies-Van Huffel 2011a, 267; cf. Plaatjies-Van Huffel 2014, 116 and Plaatjies-Van Huffel and Landman 2005, 218). This affirms the need for a relational and transformative anthropology that gives recognition to our common humanity, while noting diversity without exalting it. For Plaatjies-Van Huffel it is thus not enough to just attack concepts like patriarchy, racism, and sexism; rather, "these should be deconstructed and replaced with partnership relationships which are non-hierarchical by nature" (2011a, 269.

Plaatjies-Van Huffel's sensitivity to gender dynamics and structural oppression is also evident in the way she engaged with biblical texts. For example, at the 2017 Kirchentag in Berlin - which had as its theme Hagar's words in Genesis 16, 13: "Du siehst mich" [You see me] — she led a Bible study with Martin Heimbucher on the story of Jacob and Esau (Genesis 33:1-17). In Genesis 33:1-2 we read: "Jacob looked up, and, behold, 
Esau came, and with him four hundred men. Then Jacob distributed the children to Leah, Rachel, and the two slaves. He put the slaves and their children forward, Lea and their children behind them, behind them Rachel and Joseph." For Plaatjies-Van Huffel this immediately raises questions about how women are portrayed in the text as docile and voiceless objects, a ploy by the patriarch Jacob to soften the heart of his brother. Her concern for structural changes is also seen in her comments later in her presentation where she refers to the reconciliation scene between Jacob and his brother Esau. She recalls in this regard the South African Truth and Reconciliation Commission, and states: "The road to reconciliation requires more than forgiveness and respectful remembrance ... it requires more than kissing and hugging. Forgiveness is not about forgetting, but rather means remembering the past in a way that makes a different kind of future possible for both victim and the wrongdoer (Plaatjies-Van Huffel and Heimbucher 2017, 3). This remark also points to her concern that reconciliation is not merely about episodic meetings in which we recognise and affirm the humanity and dignity of the other, but about the commitment to a different and more just future. For her, the narrative, therefore, stands as a sign of hope for racial and religious reconciliation, indeed as a sign for overcoming, as she puts it, "divisions, enmity and conflicts from the past and the redress of social and structural injustices" (Plaatjies-Van Huffel and Heimbucher 2017, 4).

Plaatjies-Van Huffel had over the years brought these convictions-regarding gender sensitivity and the need for structural change with justice in view-to the table in numerous church and ecumenical discussions. Also concerning church life, she pointed to the fact that women have been accepted in various leadership roles, but that some theological presuppositions still keep women in submissive roles. This is seen, for instance, by the reality that very few women participate in the decision-making bodies that set the agendas or determine the policies (Plaatjies-Van Huffel 2014, 115). Therefore, the mainstreaming of gender requires a paradigm shift "in ways of thinking, as well as in the goals, structures and resource allocations, agenda setting, policy making, planning, implementation and evaluation" (Plaatjies-Van Huffel 2014, 116).

In her article "The Institutionalization of Christian Women's Organisations," PlaatjiesVan Huffel argues along the same lines that the way women's organisations were institutionalised in the Dutch Reformed Mission Church and the Dutch Reformed Church in Africa, "played a pivotal role in constituting women as docile objects in theological discourse" $(2011 b, 105)$. She points out that women were generally absent, silent or invisible in the discursive contribution of the churches that eventually formed in 1994 the Uniting Reformed Church in Southern Africa (URCSA). She also notes how the exposure of women to ecumenical discourse enabled the move from docile objects to agents of change, claiming in the process their freedom and resisting domination (2011b, 111.

I recall these aspects of Plaatjies-Van Huffel's work because they mirror something of the critique against accounts of recognition divorced from the concern for structural 
injustices (as highlighted in the previous section in conversation with scholars such as Kelly Oliver and Cillian McBride). Besides, Plaatjies-Van Huffel's contribution over the years affirms and illuminates an understanding of subjectivity and agency that powerfully challenges what McBride refers to as the recognition-deficit model that presents people primarily as passive recipients.

\section{Conclusion}

In his already-mentioned book, Recognition, Cillian McBride writes that "we are fundamentally recognition-sensitive beings and that this sensitivity plays an essential role in guiding our actions" $(2013,136)$. This observation underscores the need for responsible reflection on the notion of recognition. We should certainly be fully aware of the harmful and dehumanising effect of misrecognition and non-recognition. Therefore, the sustained presence of different expressions of resistance as part of the struggle for recognition is not surprising. Many can also witness to how generous words and gestures of recognition have proven to be identity-affirming and life-giving. This is especially the case when we experience in our encounters with others that our common humanity, as well as our particularity and difference, are affirmed. Recognition, then, is indeed about seeing the sister in the stranger and the stranger in the sister, acknowledging the brother in the other and the other in the brother. Or as the editorial introduction to the book, Recognition: An Anthology of South African Short Stories, puts it:

Interactions between individuals in a country which has a history of division are frequently convoluted and jagged, marked by suspicion and the possibility of misunderstanding. The act of recognition has a profound moral significance when it implies the valuing of other people's lives, and of their stories and histories. It may involve acknowledgement of commonality and shared humanity, of mutuality; but also the respectful awareness of difference and "otherness." (Medalie 2017, 3)

One can also assert that the concept of recognition can be linked to an optic and logic of the gift, or to what the philosopher, Paul Ricoeur, describes as the "logic of superabundance" (Ricoeur 1995, 279-283). In this sense, mutual recognition can also display a different logic than justice's logic of equivalence. In theological terms, one can even point to the doctrine of justification, according to which we are recognised by God on a fundamental level as part of the strange logic of grace.

But it would indeed be cheap grace - to use Dietrich Bonhoeffer's well-known expression in his Discipleship $(2004,44)$ - if the language of recognition is dislocated from the concerns for justice; also, as it finds expression on the juridical plane. Therefore, any responsible account of recognition will have to grapple with, and ultimately affirm, Ricoeur's question: "Can we build a bridge between the poetics of agape and the prose of justice, between the hymn and the formal rule?" (Ricoeur 2015, 224; cf. Vosloo 2015). For Ricoeur, this question is not merely meant to indicate 
difference, but moreover, to indicate the fundamental interconnectedness of justice with notions such as love, forgiveness and recognition.

In an essay in honour of Plaatjies-Van Huffel, one can certainly point towards her struggle for recognition in the church, academy, and society; also, as she documented it in her writings. It can be said that she did receive some recognition for her sustained contribution, but this does not take away that her own struggle has indeed been, as she stated with reference to Foucault, a struggle against ethnic, social and religious forms of domination, a struggle against forms of exploitation that have an alienating effect, and a struggle against harmful modes of subjectivity and submission (Plaatjies-Van Huffel 2019, 2).

One can thus say that her life and work also testify against what can be described as cheap recognition. In this context, cheap recognition would imply that women are appointed to certain positions without the concomitant task of addressing structural injustices. Therefore, her pertinent questions and comment still stand:

What differences do women bring to leadership positions, if any? In what way does the bodily presence of women influence the leadership and decision making in URCSA? Or is it business as usual? By concentrating only on the issue of access for women to ordained positions and leadership positions, there is the danger that other exclusionary mechanisms of race, culture, power structures which exist between women and men, are not being addressed (Plaatjies-Van Huffel 2019, 11).

Plaatjies-Van Huffel's work and life thus challenge discourses that are about recognition without (gender) justice; that are just about recognition and not about just recognition. This amounts to cheap recognition: that is, recognition without justice, acknowledgement without equality, inclusion without power, and hospitality that disavows the other's voice and gifts. To this we can add that cheap recognition is a symptom of an oppressive system that has a stake in keeping subjects docile and devoid of agency. It is against this background that Plaatjies-Van Huffel's contribution over many decades serves as a living reminder of an alternative imagination that can counter this deadly logic.

In the collection of South African short stories mentioned earlier - that includes several stories written after 1994 by prominent authors - the editorial introduction mentions that the selected writers of the selected stories "use the transformative power of the imagination ... to illuminate discrete instances of recognition and misrecognition." And adds: "Cumulatively these stories tell of a history tainted by misrecognition but not, finally, bound by it" (Medalie 2017, 3).

The grace bestowed on Plaatjies-Van Huffel, and that she embodied through her work and witness, is that this observation also applies to the narrative of her life. 


\section{References}

Bonhoeffer, D. 2004. Discipleship (Dietrich Bonhoeffer Works English 4). Minneapolis: Fortress Press.

Fanon, F. 1967. The Wretched of the Earth. New York: Grove Press.

Fanon, F. 2008. Black Skin, White Masks. New York: Grove Press.

Fraser, N., and A. Honneth. 2003. Redistribution or Recognition? A Political-philosophical Exchange. London, New York: Verso.

Honneth, A. 1995. The Struggle for Recognition: The Moral Grammar of Social Conflicts. Cambridge: Polity Press.

Honneth, A. 2012. The I in We: Studies in the Theory of Recognition. Cambridge: Polity Press.

Honneth, A. 2018. Anerkennung: Eine europäische Ideengeschichte. Berlin: Suhrkamp.

McBride, C. 2013. Recognition. Cambridge: Polity Press.

Medalie, D. (ed.) 2017. Recognition: An Anthology of South African Short Stories. Johannesburg: Wits University Press.

Oliver, K. 2001. Witnessing: Beyond Recognition. Minneapolis: University of Minnesota Press.

Oliver, K. 2015. "Witnessing, Recognition, and Response Ethics." Philosophy and Rhetoric 48 (4): 473-493. https://doi.org/10.5325/philrhet.48.4.0473.

Plaatjies-Van Huffel, Mary-Anne E. 2003. "Vroue in die Teologiese Antropologie van die Afrikaanse Gereformeerde Tradisie.” Unpublished doctoral thesis. Pretoria: University of South Africa.

Plaatjies van Huffel, Mary-Anne E., and C. Landman. 2005. "Vroue in die Teologiese Antropologie van die Afrikaanse Gereformeerde Tradisie." Studia Historiae Ecclesiasticae 31 (1): 203-222.

Plaatjies-Van Huffel, Mary-Anne E. 2006. "Women in the Theological Anthropology of Beyers Naudé." In Oom Bey for the Future: Engaging the Witness of Beyers Naudé, edited by L. Hansen and R. Vosloo. Stellenbosch: Sun Press, 109-120.

Plaatjies-Van Huffel, Mary-Anne E. 2011a. "Patriarchy as Empire: A Theological Reflection." Studia Historiae Ecclesiasticae 37 (3):1-13.

Plaatjies-Van Huffel, Mary-Anne E. 2011b. “The Institutionalisation of Christian Women's Organisations: From Docile Recipients to Agents of Change.” Studia Historiae Ecclesiasticae 37 (1): 105-119. 
Plaatjies-Van Huffel, Mary-Anne E., and R. Vosloo. 2013. Reformed Churches in South Africa and the Struggle for Justice: Remembering 1960-1990. Stellenbosch: Sun Press. https://doi.org/10.18820/9781920689117.

Plaatjies-Van Huffel, Mary-Anne E. 2014. "The Quest for Identity in Reformed Churches: A Gender Perspective.” In The Quest for Identity in so-called Mainline Churches in South Africa, edited by E. Conradie and J. Klaasen. Stellenbosch: African Sun Media, 108-118.

Plaatjies-Van Huffel, Mary-Anne E., and M. Heimbucher. 2017. "Dialogue Bible Study: Genesis 33:1-17 ('Jacob and Esau').” French Friedrichstadtkirche, Gendarmenmarkt, Berlin, 26 May 2017. Unpublished text.

Plaatjies-Van Huffel, Mary-Anne E. 2019. "A History of Gender Insensitivity in URCSA." Studia Historiae Ecclesiasticae 45 (3): 1-13: 22.

Ricoeur, P. 1995. Figuring the Sacred: Religion, Narrative, and Imagination. Minneapolis: Fortress Press.

Ricoeur, P. 2005. The Course of Recognition. Cambridge: Harvard University Press.

Ruether, R. R. 1983. Sexism and God-talk: Towards a Feminist Theology. London: SPCK.

Saarinen, R. 2016. Recognition and Religion: A Historical and Systematic Study. Oxford: Oxford University Press. https://doi.org/10.1093/acprof:oso/9780198791966.001.0001.

Taylor, C. 1994. "The Politics of Recognition.” In Multiculturalism, edited by Amy Gutman et al. Princeton: Princeton University Press, 25-73.

Vosloo, R. 2015. "Between the Prose of Justice and the Poetics of Love? Reading Ricoeur on Mutual Recognition in the light of Harmful Strategies of 'Othering'." Études Ricoeuriennes/Ricoeur Studies 6 (2): 105-117. https://doi.org/10.5195/ERRS.2015.309. 